\title{
PENGEMBANGAN MULTIMEDIA INTERAKTIF UNTUK PEMBELAJARAN MEMBACA ALQURAN DI PESANTREN
}

\author{
Handika Simorata Tumanggor ${ }^{1}$, Harun Sitompul ${ }^{2}$ \\ Teknologi Pendidikan Pascasarjana Universitas Negeri Medan \\ Handika_simamora@yahoo.com ${ }^{1}$
}

\begin{abstract}
Abstrak: Penelitian ini bertujuan untuk mengetahui: (1) Kelayakan multimedia interaktif untuk pembelajaran membaca Alquran di pesantren. (2) Hasil belajar siswa yang diajarkan dengan menggunakan multimedia interaktif lebih tinggi daripada hasil belajar siswa yang diajarkan dengan menggunakan media grafis sketsa pada pembelajaran membaca Alquran di pesantren. Metode penelitian pengembangan. Hasil penelitian menunjukkan bahwa kelayakan produk adalah: (1) validasi ahli materi pembelajaran berada pada kualifikasi sangat baik, (2) validasi ahli desain pembelajaran berada pada kualifikasi sangat baik, (3) validasi ahli media pembelajaran berada pada kualifikasi sangat baik, (4) uji coba terbatas berada pada kualifikasi sangat baik, (5) uji coba lebih luas berada pada kualifikasi sangat baik. Hasil pengujian hipotesis keefektifan produk menunjukkan bahwa terdapat perbedaan yang signifikan antara hasil belajar siswa yang dibelajarkan dengan menggunakan multimedia interaktif dengan hasil belajar siswa yang dibelajarkan dengan menggunakan media grafis sketsa. Hasil pengolahan data diperoleh bahwa $t_{\text {hitung }}=2,988$ pada taraf signifikasi $\alpha=0,05$ dengan $d k=78$ diperoleh $t_{\text {tabel }}=1,997$ sehingga $t_{\text {hitung }}>t_{\text {tabel }}$, disimpulkan bahwa hasil belajar membaca Alquran kelompok yang diajarkan dengan menggunakan multimedia interaktif lebih tinggi daripada kelompok yang diajarkan dengan menggunakan media grafis sketsa.
\end{abstract}

Kata Kunci: pengembangan multimedia interaktif, pembelajaran membaca alquran, pesantren

\begin{abstract}
This study aims to determine: (1) Eligibility interactive multimedia for learning to read the Koran in schools. (2) The results of student learning is taught using interactive multimedia learning outcomes are higher than students taught by using graphic media sketch on learning to read the Koran in schools. The research method development. The results showed that the eligibility of products are: (1) expert validation of learning materials that are in excellent qualifications, (2) validation expert instructional design that are in excellent qualifications, (3) validation expert instructional media that are in excellent qualifications, (4) limited trial are in excellent qualifications, (5) more extensive trials are in excellent qualifications. Results of hypothesis testing the effectiveness of the product indicate that there are significant differences between student learning outcomes that learned using interactive multimedia learning outcomes of students that learned by using graphic media sketch. The result of data processing obtained that $\mathrm{t}=$ 2.988 at significance level $\alpha=0.05 \mathrm{df}=78$ obtained table $=1.997$ so thitung $>$ ttable, concluded that the results of learning to read the Koran groups taught by using interactive multimedia higher than the group taught by using graphic media sketch.
\end{abstract}

Keywords: interactive multimedia development, learning to read the Quran, boarding

\section{PENDAHULUAN}

Berangkat dari besarnya peranan dan luasnya kandungan Alquran, maka dunia pendidikan Islam tidak bisa begitu saja mengabaikannya. Alquran yang diyakini sebagai petunjuk bagi umat manusia, secara nyata menempati posisi penting dalam pemikiran dan peradaban umat Islam. Gusmian (2003:49) menyebutkan, sejak awal masa pergumulan Islam di Indonesia berbagai pondok pesantren, madrasah, dan sekolah telah memposisikan Alquran menjadi salah satu materi penting yang dipelajari di samping fiqh, bahasa, dan teologi maupun keilmuan Islam lainnya.

Alquran juga merupakan wahyu Allah yang diturunkan dengan bahasa Arab. Hal yang sedemikian ini, karena Nabi yang menerimanya berasal dari bangsa Arab dan berbicara dalam bahasa Arab. Bahasa ini, sebagaimana bahasa- 
bahasa lain memiliki gramatikal dan cara baca yang khas dan berbeda dari bahasa lainnya. Kaum muslimin yang berasal dari keturunan non-Arab tentu mengalami kesulitan dalam membacanya bila mereka tidak mempelajari bahasa Arab ini dengan baik. Karena itu mereka dianjurkan untuk mempelajari bahasa ini agar mereka dapat memahami Kitab Suci dengan benar. Satu hal yang perlu diperhatikan bahwa cara membaca Alquran tidak sama dengan membaca buku-buku yang berbahasa Arab. Maksudnya adalah Alquran memiliki aturanaturan khusus dalam membacanya. Bahkan para ulama sepakat bahwa membaca Alquran dengan cara khusus, yaitu dengan menggunakan kaidah tajwid, wajib hukumnya menggunakan tajwid bagi mereka yang membacanya. Kesalahan dalam membaca Alquran yang tidak sesuai dengan tajwid akan dapat mengubah makna atau maksud sesungguhnya. Allah SWT menegaskannya dalam Alquran surat Muzammil ayat 4 yang artinya: "Dan bacalah Alquran itu dengan tartil". Ali bin Abi Thalib dalam (Al-Mujahid: 2010) menjelaskan tentang makna ayat ini "At-Tartilu tajwidul hurufi wa ma'rifatul wuqufi" artinya makna Tartil dalam ayat ini adalah memperbagus huruf dan mengetahui waqf. Itu artinya seseorang yang membaca Alquran, baik tanpa lagu maupun dilagukan dengan indah dan merdu, tidak boleh terlepas dari kaidah ilmu tajwid. Yaitu ilmu yang berguna untuk mengetahui bagaimana cara untuk memenuhkan/memberikan hak huruf dan mustahaq-nya. Maka implikasinya kompetensi membaca Alquran seseorang akan baik jika mampu memahami dan menerapkan kaidah-kaidah tajwid dalam membaca Alquran.

Akaha (2004:10) memaparkan bahwa tak banyak orang yang tertarik pada ilmu tajwid, hal ini berimbas menjadi sedikitnya orang yang ingin bisa membaca Alquran dengan benar yang sesuai dengan kaidah tajwid, tepat makhraj dan shifat hurufnya sebagaimana Alquran diturunkan. Banyak orang yang menganggap, sekedar bisa lancar membaca Alquran sudah cukup. Sehingga, banyak orang yang lancar membaca Alquran, namun secara kaidah tajwid masih banyak kesalahannya.

Alquran yang merupakan sumber ajaran Islam jelas menempati posisi penting dalam agenda pendidikan Islam, selanjutnya hal ini berimbas pada pembentukan tradisi kurikuler di pondok pesantren yang menjadikan Alquran sebagai materi pembelajaran yang mendapat perhatian serius seperti yang di kemukakan Nafi dkk (2006:12) bahwa di kebanyakan pondok pesantren paket materi pembelajaran Alqur'annya dimulai dari tataran membaca, menghafalkan surah-surah pendek, membaca keseluruhan juz, menghafalkan surah-surah diluar Juz Amma (juz ke-30) hingga menghafal keseluruhan juz Alquran. Dalam mata pelajaran tajwid, kegiatan pembelajarannya dimulai dari praktek dan menirukan guru, mengkaji Hidayat ash-Shibyan, Mushthalah at-Tajwid, alJazariyah, jika dikembangkan akan sampai ke al-Burhan dan at-Tibyan fi Adab Hamalat Alquran.

Suparman (2001) memaparkan bahwa media gambar hidup (visual bergerak) sangat baik untuk ketercapaian belajar prosedur maupun keterampilan. Pernyataan kedua pendapat tadi berkaitan dengan pendapat Dale yang menyatakan bahwa pemerolehan hasil belajar melalui indra pandang berkisar $75 \%$, melalui indra dengar sekitar $13 \%$, dan melalui indra lainnya sekitar $12 \%$. Hal senada ditegaskan oleh Baugh (1986) yang menyatakan bahwa kurang lebih $90 \%$ hasil belajar seseorang diperoleh melalui indra pandang, 5\% diperoleh melalui indra dengar, dan 5\% lagi diperoleh melalui indra lainnya.

Annuri (2010: 6) menjelaskan tentang tujuan yang menjadi target atau sasaran dalam pembelajaran membaca Alquran antara lain: (1) Terciptanya kemampuan melafalkan hurufhuruf dengan baik dan benar, sesuai dengan makhraj dan sifatnya. (2) Terciptanya kemampuan membaca ayat-ayat Alquran sesuai dengan hukum-hukum tajwid. (3) Terciptanya kemampuan membaca ayat-ayat Alquran dengan lancar, dengan tetap memperhatikan kaidah-kaidah tajwid. (4) Terciptanya kemampuan menguasai kaidah-kaidah ilmu tajwid, karena bagi pembaca Alquran (qori) yang memahami dan menguasai kaidah-kaidah tajwid, kecil kemungkinannya melakukan kesalahan dalam membaca Alquran , di sisi lain ia mampu mengajarkannya kepada keluarga dan masyarakat.

Annuri (2010: 7-8) menawarkan beberapa kiat sukses dalam belajar membaca Alquran antara lain: 1) tekad dan niat yang ikhlas, 2) yakin 3) talaqqi kepada guru, 4) disiplin dan kontiniu belajar, 5) membiasakan membaca dengan satu mushaf 6) menerapkan target-target yang harus dicapai secara kuantitas maupun kualitas, 7) banyak mendengarkan bacaan murattal, 8) membuka diri untuk menerima nasehat. Annuri (2010: 9-11) 
menjelaskan bahwa nilai-nilai/keutamaan yang terkandung dalam membaca Alquran antara lain: (1) ta'abbudan lillah (sebagai bentuk ibadah kepada Allah). (2) tarsikhan lil iman (memperkokoh keimanan). (3) tazkiyatan lin nufus (menyucikan jiwa). (4) taqwiman lil fikrah (meluruskan pola pikir) (5) ta'arrufan bimanhajillah (mengenal ajaran Allah).

Seseorang yang membaca Alquran, baik dengan tanpa lagu maupun dilagukan dengan indah dan merdu, tidak boleh terlepas dari kaidah ilmu tajwid. Secara etimologi kata "tajwid" berasal dari kata "jawwadayujawwidu-tajwiidan" yang berarti membaguskan, menyempurnakan, memantapkan (Ma'louf: 2000). Sedangkan secara terminologi, Salim (2009) memaparkan bahwa ilmu tajwid adalah ilmu yang berguna untuk mengetahui bagaimana cara memberikan hak huruf (sifat asli yang selalu melekat pada huruf) dan mustahaq-nya (sifat kondisional yang tampak sewaktu-waktu atau dalam kondisi tertentu ada padanya). Baik yang berkaitan dengan sifat, mad dan sebagainya, seperti tarqiq, dan tafkhim dan selain keduanya.

Abu Amr Ad-Dani seperti dikutip AlMujahid (2011: 21) menerangkan tentang halhal perlu dijauhi oleh para pengajar Alquran sebagai berikut:

Tajwid bukanlah dengan mengunyah-ngunyah lidah, memperdalam mulut, membengkokbengkokkan dagu, menggetar-getarkan suara, memulurkan syiddah, memotong-motong madd, memperpanjang dengung ghunnah, menggemukkan $\mathrm{ra}^{\prime}$, bukan pula bacaan yang dijauhi karakter manusia normal, ataupun bacaan yang ditolak oleh telinga dan hati nurani, tetapai tajwid adalah bacaan yang mudah, enak manis dan lembut, tanpa mengunyah-ngunyah, mengulum-ngulum, ta'asuf, takalluf, dibuat-buat, tanpa berlebihan ataupun memperberat diri, serta tidak keluar dari karakter normal orang Arab.

Al-Qamhawi (1993: 1993) mengatakan bahwa tujuan mempelajari ilmu tajwid adalah untuk menjaga lidah dari kesalahan di saat membaca Alquran. Al-Mujahid (2011) menerangkan bahwa tujuan mempelajari dan mengamalkan ilmu tajwid adalah menjaga lisan kita dari lahn (kesalahan) ketika membaca Alquran, hadis, do'a-do'a dalam shalat maupun di luar shalat. Orang yang membacanya dengan tanpa tajwid maka akan terjerumus ke dalam lahn (kesalahan) yang berdampak negatif terhadap nilai ibadahnya, mengurangi pahala, atau bahkan membatalkannya bila ada unsur sengaja.

Ibnu Jazari dalam Salim (2009) menjelaskan bahwa menggunakan tajwid (dalam membaca Alquran) adalah wajib, barang siapa yang tidak membaguskan bacaan Alquran (sesuai kaidah tajwid) maka ia akan berdosa, karena dengannyalah (tajwid) Allah menurunkan Alquran, dan beginilah (Alquran dengan tajwidnya) sampai kepada kita. Seseorang bisa sampai pada tajwid dengan memperbanyak latihan dan talaqqi dari guru yang mutqin (menguasai ilmunya) dan ahli dalam mengajar (Annuri 2010).

Media adalah perantara atau pengantar pesan dari pengirim ke penerima pesan (Sadiman,dkk: 2002). Association for Educational Communication and Technology (AECT) sebagaimana dikutip Miarso (2009: 457) mengartikan media sebagai segala bentuk dan salkuran yang dipergunakan untuk proses transmisi informasi. Briggs (1970) mendefinisikan media sebagaimana dikutip dalam Reigeluth (1983): "instructional media broadly as all means by which stimuli are presented to provide the events of instruction. In this sense, media include the full range of audiovisual materials, print, and the voices of the teacher and learner." Yang mengandung arti bahwa secara luas media pembelajaran adalah sebagai semua sarana di mana rangsangan disajikan untuk menyediakan kegiatan pengajaran. Dalam pengertian ini, media termasuk berbagai bahan audiovisual, mencetak, dan suara para guru dan pelajar

Miarso (2009: 458) mengemukakan bahwa media belajar adalah segala sesuatu yang digunakan untuk menyalurkan pesan serta dapat merangsang pikiran, perasaan, perhatian dan kemauan siswa sehingga dapat mendorong terjadinya proses belajar yang disengaja, bertujuan, dan terkendali. Menurut Bovee dalam Ouda Teda Ena (2001), Media adalah sebuah alat yang mempunyai fungsi menyampaikan pesan. Pembelajaran adalah sebuah proses komunikasi antara siswa, pengajar dan bahan ajar. Komunikasi tidak dapat berjalan tanpa bantuan sarana penyampai pesan atau media. Gerlach dan Ely dalam Arsyad (2006) mengatakan bahwa media apabila dipahami secara garis besar adalah manusia, materi, atau kejadian yang membangun kondisi yang membuat siswa mampu memperoleh pengetahuaan, keterampilan, atau sikap. Secara lebih khusus, 
pengertian media dalam proses belajar mengajar cenderung diartikan sebagai alat-alat grafis, photografis, atau elektronis untuk menangkap, memproses, dan menyusun kembali informasi visual atau verbal.

Berdasarkan persepsi indera, media diklasifikasikan menjadi tiga kelas, yakni media audio, media visual, dan media audio visual (Sanaky: 2011: 42). Media audio, yaitu media yang menghasilkan bunyi atau suara. Media ini dapat menyalurkan pesan melalui bunyi atau suara. Contoh media jenis ini adalah radio dan audio cassette tape recorder. Media visual, yakni media yang menghasilkan bentuk atau rupa, yang dikenal sebagai media peraga. Contoh media visual adalah gambar alat transfortasi, insektarium, tiruan rangka manusia, dan lain-lain. Media visual dibedakan menjadi dua jenis, yaitu (1) media visual dua dimensi dan (2) media visual tiga dimensi. Media audio visual, yaitu media yang dapat menghasilkan rupa dan suara dalam satu unit media. Contoh jenis media ini adalah video, film bersuara, dan televisi.

Berdasarkan cara penggunaannya media pembelajaran dibedakan menjadi dua, yakni media pembelajaran yang penggunaannya secara (1) tradisional atau konvensional (sederhana) dan (2) modern atau kompleks. Dari segi kompleksitas dan besarnya biaya, Schramm seperti dikutip Sanaky (2011) membedakan antara media rumit dan mahal (big media) dan media sederhana (little media). Contoh big media adalah video pembelajaran dan siaran televisi pendidikan. Contoh little media adalah gambar binatang, sketsa perkembangbiakan katak. Schramm juga menggelompokkan media menurut kemampuan daya liputnya, yaitu: 1) liputan luas dan serempak seperti TV, Radio, dan faxsimile, 2) liputan terbatas pada tempat/ruangan seperti film, video, slide, poster audio tape, dan sebagainya, 3) media untuk belajar individual (mandiri) seperti buku, modul, program belajar

Mayer (2001) menyatakan bahwa multimedia adalah berupa kombinasi antara teks, grafik, animasi, suara dan gambar. Namun pada bagian ini perpaduan dan kombinasi dua atau lebih jenis media ditekankan kepada kendali komputer sebagai penggerak keseluruhan gabungan media ini. Penggabungan ini merupakan suatu kesatuan yang secara bersama-sama menampilkan informasi, pesan atau isi pelajaran (Arsyad, 2002:169). Konsep penggabungan ini dengan sendirinya memerlukan beberapa jenis peralatan perangkat keras yang masing-masing tetap menjalankan fungsi utamanya sebagaimana biasanya, dan komputer merupakan pengandali seluruh peralatan itu. Jenis peralatan itu adalah komputer, video kamera, video cassette recorder (VCR), overhead projector, CD Player, compact disc. Kesemua peralatan ini haruslah kompak dan bekerjasama dalam menyampaikan informasi kepada pemakainya.

Chapman \& Chapman (2004: 8) menyatakan bahwa bentuk multimedia sebagai alat penyampai pesan dibedakan menjadi dua yaitu online delivery dan offline delivery. Online delivery adalah multimedia yang menggunakan suatu jaringan untuk menyampaikan informasi dari satu komputer atau server machine yang menjadi pusat penyimpan data ke jaringan lain baik jaringan lokal dalam suatu organisasi maupun jaringan internet. Offline delivery adalah multimedia yang disimpan dengan menggunakan suatu alat penyimpan atau kemasan yang dapat dipindahkan. Alat penyimpan tersebut harus mampu menyimpan data yang besar sesuai dengan ciri-ciri data

Philips (1997: 12) menyatakan bahwa "IMM has the potential to accommodate people with different learning style". Artinya adalah bahwa multimedia interaktif dapat mengakomodasi cara belajar yang berbedabeda. Lebih lanjut Philips (1997: 12) menyatakan bahwa multimedia interaktif memiliki potensi untuk menciptakan suatu lingkungan multisensori yang mendukung cara belajar tertentu. Berdasarkan hal tersebut, multimedia dalam proses belajar mengajar dapat digunakan dalam tiga fungsi, yaitu sebagai berikut: (1) alat bantu instruksional. (2) tutorial interaktif, misalnya dalam simulasi. (3) sumber petunjuk belajar, misalnya, multimedia digunakan untuk menyimpan serangkaian slide mikroskop atau radiograf.

Multimedia/hypermedia mempunyai prospek yang tinggi dan powerfull digunakan untuk pembelajaran dan pelatihan Collins, Hammond \& Wellington (2002). Sayangnya menurut beberapa ahli sebagaimana dikutip Sudatha \& Tegeh (2002) banyak multimedia yang dibuat dan disampaikan (delivery) lewat $e$ learning ataupun on-line learning belum mencermati aspek kualitas secara konsisten (Leacock \& Nesbit, 2007), belum banyak mencermati proses kognisi manusia (Clark \& Mayer, 2003), dan belum mengadopsi hasil riset 
psikologi pendidikan (Nesbit, Li \& Leacock, 2006; Shavinina \& Loarer, 1999).

Multimedia mencakup berbagai jenis media yang terintegrasi menjadi satu. Setiap komponen media dapat merangsang satu atau lebih indra manusia. Teori Koehnert mengatakan bahwa semakin banyak indra yang terlibat dalam proses belajar, maka proses belajar tersebut akan menjadi lebih efektif. Secara tegas teori ini menyarankan penggunaan lebih dari satu indera manusia. Oleh karena itu, pemanfaatan multimedia dalam pembelajaran dapat diharapkan meningkatkan hasil belajar seperti yang diungkapkan Schramm dalam (Sanjaya 2005). "We must not forget that almost all teaching is Multimedia". Pernyataan tadi berkaitan dengan pendapat Dale yang menyatakan bahwa pemerolehan hasil belajar melalui indra pandang berkisar $75 \%$, melalui indra dengar sekitar $13 \%$, dan melalui indra lainnya sekitar $12 \%$. Hal senada ditegaskan oleh Baugh dalam Arsyad (2006) yang menyatakan bahwa kurang lebih 90\% hasil belajar seseorang diperoleh melalui indra pandang, 5\% diperoleh melalui indra dengar, dan 5\% lagi diperoleh melalui indra lainnya.

Reinhardt juga mengidentifikasi cara bagaimana multimedia dapat meningkatkan kualitas pembelajaran dalam Snyder (1996). Reinhardt menjelaskan secara lebih rinci bahwa: (1) multimedia dapat meningkatkan rasa ingin-tahu, kreativitas, dan kerjasama kelompok; (2) multimedia dapat mengubah peran guru tradisional menjadi dari guru modern; (3) menggunakan multimedia akan dapat mengingatkan kembali model pembelajaran; (4) multimedia dapat meningkatkan akses informasi; (5) multimedia dapat menyediakan bahan yang lebih untuk bisa mengarah kepada "media overload"; dan (6) multimedia kita tidak lagi terkungkung dalam kelas, tapi bisa melangkah lebih maju.

Secara umum, pembelajaran multimedia dapat memotivasi pebelajar dan menciptakan belajar aktif (Muller, Lee, \& Sharma, 2008), namun efektivitasnya dilihat dari pencapaian hasil belajar ternyata tidak konsisten (Leacock, \& Nesbit, 2007; Park \& Lim, 2007). Deiman \& Keller (2006) menduga kurang konsistennya hasil pembelajaran menggunakan multimedia/hypermedia disebabkan oleh desain multimedia hanya menekankan aspek kognisi, mengabaikan aspek motivasi, padahal motivasi memegang peran yang sangat penting dalam belajar. Kurangnya kemampuan dalam memanfaatkan navigasi dan perangkat bantuan merupakan penyebab kurang efektifnya belajar terbuka (open learning environment) (Clarebout \& Elen, 2008).

Macromedia Flash merupakan salah satu software animasi yang sudah tidak asing lagi bagi kebanyakan orang yang berkecimpung dalam pembuatan program animasi. Lukmanul Hakim (2004) menyebutkan bahwa Macromedia Flash Professional 8.0 merupakan alat yang sangat bagus untuk desainer web, praktisi media interaktif, atau praktisi multimedia. Penekanan Flash untuk pembuatan (kreasi) animasi, serta mengimpor dan memanipulasi berbagai tipe media (audio, video, bipmap, vektor, teks, grafik, dan data).

Rumusan masalahnya penelitian adalah: (1) Bagaimana kelayakan multimedia interaktif untuk pembelajaran membaca Alquran di pesantren?; (2) Apakah hasil belajar siswa yang diajarkan dengan menggunakan multimedia interaktif lebih tinggi daripada hasil belajar siswa yang diajarkan dengan menggunakan media grafis sketsa pada pembelajaran membaca Alquran di pesantren?

\section{METODE}

Penelitian pengembangan dilaksanakan di Pesantren Ar-Raudhatul Hasanah Medan yang beralamat di Jl. Jamin Ginting Km.11 Paya Bundung Medan. Pesantren ini dipilih sebagai tempat penelitian karena peneliti memiliki akses pada pesantren tersebut, peneliti juga pernah berdomisili di lokasi tersebut, sehingga memungkinkan bagi peneliti melakukan penelitian lebih mendalam dan intensif, serta peneliti juga pernah staf pengajar bidang studi tajwid Alquran pada pesantren tersebut. Selain itu dipilihnya pesantren ini sebagai lokasi penelitian karena pertimbangan bahwa pelajaran membaca Alquran (tajwid) termasuk salah satu pelajaran kurikuler yang diajarkan di dalam kelas.

Penelitian ini menggunakan metode Penelitian dan Pengembangan Pendidikan (Educational Research and Development). Borg dan Gall (1983) mengemukakan bahwa penelitian pengembangan pendidikan yaitu " $a$ process used develop and validate educational product", yaitu sebuah proses yang digunakan untuk mengembangkan dan menvalidasi produk pendidikan. Langkah-langkah dalam penelitian ini mengarah kepada siklus yang berdasarkan kajian dan temuan penelitian, kemudian 
dikembangkan suatu produk yang didasarkan pada temuan studi pendahuluan, diuji dalam suatu situasi dan dilakukan revisi terhadap hasil uji coba sampai pada akhirnya diperoleh suatu produk yang dapat digunakan untuk mencapai tujuan penelitian.

Tahap perencanaan dan pengembangan multimedia interaktif ini dilakukan sebelum uji coba dilaksanakan. Tahap ini meliputi beberapa langkah yang dipadukan dengan pengembangan pembelajaran model Dick, Carey dan Carey (2005).

Uji coba produk berbentuk multimedia pembelajaran interaktif yang telah dikembangkan dan merevisinya merupakan bagian yang sangat penting dalam penelitian dan pengembangan ini, yang dilakukan setelah pengembangan multimedia interaktif telah selesai dan telah menghasilkan produk awal yang siap untuk diuji coba efektifitasnya. Pada tahap ini peneliti melakukan kegiatan uji coba melalui implementasi multimedia interaktif yang dikembangkan. Uji coba multimedia interaktif bertujuan untuk mengetahui efektifitas multimedia interaktif yang dikembangkan yaitu apakah layak digunakan atau belum, dan sejauh mana produk yang dibuat dapat mencapai sasaran dan tujuan. Ada tiga tahapan dalam uji coba multimedia interaktif dalam penelitian pengembangan ini, yaitu: (1) uji/validasi kepada ahli (expert judgement), (2) ujicoba terbatas (preliminary field

Tabel 1. Desain Eksperimen Randomized Subjects Pretes-Postest Control Group Design

\begin{tabular}{|c|l|c|c|c|}
\hline Subjek & \multicolumn{1}{|c|}{ Grup } & Pretes & Variabel Terikat & Postes \\
\hline $\mathrm{R}$ & Eksperimen & $\mathrm{Y}_{1}$ & $\mathrm{X}_{1}$ & $\mathrm{Y}_{2}$ \\
\hline $\mathrm{R}$ & Kontrol & $\mathrm{Y}_{3}$ & $\mathrm{X}_{2}$ & $\mathrm{Y}_{4}$ \\
\hline
\end{tabular}

Pada tahap pengembangan data dideskripsikan dalam bentuk sajian data, kemudian dianalisis secara kualitatif, pada tahap uji ahli dan uji coba terbatas, hasil ujicoba penerapan desain multimedia interaktif dianalisis dengan pendekatan analisis deskriptif kuantitatif, pada ujicoba lebih luas menggunakan pendekatan analisis deskriptif kuantitatif, kemudian terakhir pada tahap uji efektifitas produk untuk menguji hipotesis eksperimen ujicoba digunakan analisis statistik (kuantitatif) dengan teknik analisis satu jalur yaitu dengan formula statistik uji $\mathrm{t}$ ( $t$ test) dengan taraf signifikansi $\alpha=0.05$, uji ini digunakan untuk mengukur efektifitas penerapan multimedia interaktif dengan cara membandingkan hasil belajar tajwid antara kelompok yang diajarkan menggunakan multimedia interaktif dengan kelompok yang diajarkan menggunakan media grafis sketsa.

Sebelum pengujian hipotesis, dilakukan uji persyaratan analisis, antara lain uji normalitas data penelitian yang menggunakan uji Liliefors, kemudian dilanjutkan uji homogenitas yang menggunakan uji Fisher (F). Adapun rumusan pengujian hipotesis statistiknya untuk uji coba dinyatakan sebagai berikut:

$\mathrm{H}_{\mathrm{o}}: \mu \mathrm{Mi} \leq \mu \mathrm{Gs}$
$\mathrm{H}_{\mathrm{a}}: \mu \mathrm{Mi}>\mu \mathrm{Gs}$

Keterangan :

$\mu \mathrm{Mi}=$ Hasil belajar membaca Alquran yang diajarkan denganmultimedia interaktif

$\mu \mathrm{Gs}=$ Hasil belajar membaca Alquran yang diajarkan dengan media grafis sketsa

$\mathrm{H}_{\mathrm{o}}$ (Hipotesis uji coba ditolak) apabila hasil belajar membaca Alquran yang diajarkan dengan multimedia interaktif sama atau lebih rendah secara signifikan daripada yang diajarkan dengan media grafis sketsa. Sedangkan $\mathrm{H}_{\mathrm{a}}$ (Hipotesis uji coba diterima) apabila hasil belajar membaca Alquran yang diajarkan dengan multimedia interaktif lebih tinggi secara signifikan daripada yang diajarkan dengan media grafis sketsa.

\section{HASIL DAN PEMBAHASAN Hasil}

Validasi ahli materi pembelajaran terhadap pengembangan Multimedia Pembelajaran Interaktif pada Pembelajaran Alquran dilakukan oleh tokoh yang kompeten menguasai materi yang diajarkan yaitu ahli ilmu tajwid, Adapun data hasil validasi ahli desain pembelajaran dapat dilihat pada Tabel 2 berikut:

Tabel 2. Data Hasil Validasi Kelayakan Multimedia Interaktif Oleh Ahli Materi Pembelajaran 


\begin{tabular}{|c|c|c|c|c|c|c|}
\hline \multirow{2}{*}{ No } & \multirow{2}{*}{ Indikator } & \multicolumn{2}{|c|}{ Responden } & \multirow{2}{*}{$\begin{array}{l}\text { Jumlah } \\
\text { Skor }\end{array}$} & \multirow{2}{*}{$\begin{array}{l}\text { Rata } \\
\text { rata }\end{array}$} & \multirow{2}{*}{ Kriteria } \\
\hline & & 1 & 2 & & & \\
\hline 1 & Kesesuaian materi dengan kompetensi & 5 & 5 & 10 & 5 & sangat baik \\
\hline 2 & Kebenaran isi materi & 5 & 5 & 10 & 5 & sangat baik \\
\hline 3 & Keluasan isi materi & 4 & 5 & 9 & 4,5 & sangat baik \\
\hline 4 & Kedalaman isi materi & 5 & 5 & 10 & 5 & sangat baik \\
\hline 5 & Kejelasan isi materi & 5 & 5 & 10 & 5 & sangat baik \\
\hline 6 & Ketepatan urutan materi pembelajaran & 5 & 5 & 10 & 5 & sangat baik \\
\hline 7 & $\begin{array}{l}\text { Ketercernaan materi dan pemaparan yang } \\
\text { logis }\end{array}$ & 4 & 4 & 8 & 4 & Baik \\
\hline 8 & Kejelasan contoh yang disertakan & 4 & 5 & 9 & 4,5 & sangat baik \\
\hline 9 & Ketepatan contoh yang disertakan & 5 & 5 & 10 & 5 & sangat baik \\
\hline 10 & Kejelasan gambar yang disertakan & 5 & 5 & 10 & 5 & sangat baik \\
\hline 11 & Ketepatan gambar yang disertakan & 5 & 5 & 10 & 5 & sangat baik \\
\hline 12 & Kejelasan animasi yang disertakan & 5 & 5 & 10 & 5 & sangat baik \\
\hline 13 & Ketepatan animasi yang disertakan & 5 & 5 & 10 & 5 & sangat baik \\
\hline 14 & Kesesuaian latihan dengan kompetensi & 4 & 5 & 9 & 4,5 & sangat baik \\
\hline 15 & Kualitas latihan yang diberikan & 5 & 5 & 10 & 5 & sangat baik \\
\hline 16 & Kesesuaian soal tes dengan kompetensi & 4 & 5 & 9 & 4,5 & sangat baik \\
\hline 17 & Kualitas soal tes yang diberikan & 5 & 4 & 8 & 4,5 & sangat baik \\
\hline 18 & Tingkat kesulitan soal yang diberikan & 5 & 4 & 9 & 4,5 & sangat baik \\
\hline 19 & $\begin{array}{l}\text { Keseimbangan proporsi soal tes dengan } \\
\text { materi }\end{array}$ & 5 & 5 & 10 & 5 & sangat baik \\
\hline 20 & Kesesuaian bahasa dengan usia pengguna & 4 & 4 & 8 & 4 & Baik \\
\hline & PRESENTASE & & & & $95 \%$ & sangat baik \\
\hline
\end{tabular}

Kesimpulan hasil penilaian ahli materi pembelajaran secara keseluruhan disimpulkan bahwa jumlah nilai rata-rata dari indikator tersebut adalah 95\%. Dimana jika rentang berada pada skor $81 \% \leq X \leq 100 \%$ maka kecenderungan penilaian ahli materi dinyatakan kategori "sangat layak".

Validasi ahli desain pembelajaran terhadap pengembangan Multimedia Pembelajaran Interaktif Pembelajaran Membaca Alquran Adapun data hasil validasi ahli desain pembelajaran dapat dilihat pada Tabel 3 berikut:

Tabel 3. Data Hasil Validasi Kelayakan Multimedia Interaktif Oleh Ahli Desain Pembelajaran

\begin{tabular}{|c|l|c|c|c|c|c|}
\hline \multirow{2}{*}{ No } & \multicolumn{1}{|c|}{ Indikator } & \multicolumn{2}{|c|}{ Responden } & Jumlah \\
\cline { 2 - 7 } & \multicolumn{1}{|c|}{$\begin{array}{c}\text { Rkor } \\
\text { rata }\end{array}$} & Kriteria \\
\hline 1 & $\begin{array}{l}\text { Kejelasan tujuan pembelajaran dapat } \\
\text { terukur }\end{array}$ & 4 & 5 & 9 & 4,5 & Sangat baik \\
\hline 2 & $\begin{array}{l}\text { Kesesuaian kompetensi dasar dengan } \\
\text { standar kompetensi }\end{array}$ & 5 & 5 & 10 & 5 & Sangat baik \\
\hline 3 & $\begin{array}{l}\text { Kesesuaian indikator dengan kompetensi } \\
\text { dasar }\end{array}$ & 5 & 5 & 10 & 5 & Sangat baik \\
\hline 4 & Kejelasan sasaran pengguna & 4 & 4 & 8 & 4 & baik \\
\hline 5 & $\begin{array}{l}\text { Kesesuaian penggunaan bahasa dengan usia } \\
\text { pengguna }\end{array}$ & 4 & 4 & 8 & 4 & baik \\
\hline 6 & $\begin{array}{l}\text { Program memfasilitasi siswa untuk } \\
\text { mengkonstruksi pengetahuannya sendiri }\end{array}$ & 4 & 4 & 8 & 4 & baik \\
\hline 7 & Merangsang kreatifitas siswa & 5 & 5 & 10 & 5 & Sangat baik \\
\hline 8 & $\begin{array}{l}\text { Mendukung aspek kemandirian siswa } \\
\text { dalam belajar }\end{array}$ & 5 & 5 & 10 & 5 & Sangat baik \\
\hline 9 & Kejelasan judul program & 5 & 4 & 9 & 4,5 & Sangat baik \\
\hline 10 & Kesesuaian materi dengan indikator & 5 & 4 & 9 & 4,5 & Sangat baik \\
\hline
\end{tabular}




\begin{tabular}{|c|c|c|c|c|c|c|}
\hline \multirow{2}{*}{ No } & \multirow{2}{*}{ Indikator } & \multicolumn{2}{|c|}{ Responden } & \multirow{2}{*}{$\begin{array}{l}\text { Jumlah } \\
\text { Skor }\end{array}$} & \multirow{2}{*}{$\begin{array}{l}\text { Rata } \\
\text { rata }\end{array}$} & \multirow{2}{*}{ Kriteria } \\
\hline & & 1 & 2 & & & \\
\hline & pembelajaran & & & & & \\
\hline 11 & Kecukupan pemberian contoh & 4 & 4 & 8 & 4 & baik \\
\hline 12 & Relevansi latihan dengan kompetensi & 5 & 5 & 10 & 5 & Sangat baik \\
\hline 13 & $\begin{array}{l}\text { Merangsang siswa untuk melatih } \\
\text { kemampuan psikomotoriknya }\end{array}$ & 5 & 4 & 9 & 4,5 & Sangat baik \\
\hline 14 & $\begin{array}{l}\text { Kesesuaian alur program dengan strategi } \\
\text { pembelaiaran }\end{array}$ & 4 & 5 & 9 & 4,5 & Sangat baik \\
\hline 15 & $\begin{array}{l}\text { Ketepatan pendahuluan memotivasi } \\
\text { pengguna }\end{array}$ & 4 & 4 & 8 & 4 & baik \\
\hline 16 & $\begin{array}{l}\text { Penggunaan petunjuk belajar (petunjuk } \\
\text { penggunaan) }\end{array}$ & 4 & 4 & 8 & 4 & baik \\
\hline 17 & $\begin{array}{l}\text { Kemenarikan program memotivasi } \\
\text { pengguna }\end{array}$ & 4 & 4 & 8 & 4 & baik \\
\hline 18 & Kejelasan petunjuk pengerjaan soal tes & 5 & 4 & 9 & 4,5 & Sangat baik \\
\hline 19 & $\begin{array}{l}\text { Keseimbangan proporsi jumlah soal tes } \\
\text { dengan materi }\end{array}$ & 5 & 4 & 9 & 4,5 & Sangat baik \\
\hline 20 & $\begin{array}{l}\text { Umpan balik terhadap hasil tes peserta } \\
\text { didik }\end{array}$ & 5 & 4 & 9 & 4,5 & Sangat baik \\
\hline \multicolumn{5}{|c|}{ PERSENTASE } & $89 \%$ & Sangat Baik \\
\hline
\end{tabular}

Kesimpulan hasil penilaian ahli desain pembelajaran secara keseluruhan maka disimpulkan bahwa jumlah nilai rata-rata dari indikator tersebut adalah $89 \%$. Dimana jika rentang berada pada skor $81 \% \leq \mathrm{X} \leq 100 \%$ maka kecenderungan penilaian ahli desain pembelajaran dinyatakan kategori "sangat layak".

Validasi ahli media pembelajaran terhadap pengembangan Multimedia Interaktif Pembelajaran Membaca Alquran Adapun data hasil validasi ahli media pembelajaran dapat dilihat pada Tabel 4 berikut:

Tabel 4. Data Hasil Validasi Kelayakan Multimedia Interaktif Oleh Ahli Media Pembelajaran

\begin{tabular}{|l|l|c|c|c|c|c|}
\hline \multirow{2}{*}{ No } & \multicolumn{1}{|c|}{ Indikator } & \multicolumn{2}{c|}{ Responden } & Jumlah & Rata & Kror \\
rata & & $\mathbf{1}$ & $\mathbf{2}$ & Kriteria \\
\hline 1 & Kemudahan penggunaan program & 4 & 5 & 9 & 4,5 & Sangat Baik \\
\hline 2 & Kemudahan memilih menu program & 5 & 5 & 10 & 5 & Sangat Baik \\
\hline 3 & Konsistensi dengan alur program & 4 & 5 & 9 & 4,5 & Sangat Baik \\
\hline 4 & Efisiensi sistem & 5 & 4 & 9 & 4,5 & Sangat Baik \\
\hline 5 & Ketepatan fungsi button & 5 & 5 & 10 & 5 & Sangat Baik \\
\hline 6 & Kecepatan reaksi button & 5 & 4 & 9 & 4,5 & Sangat Baik \\
\hline 7 & Konsistensi antar bagian halaman & 5 & 5 & 10 & 5 & Sangat Baik \\
\hline 8 & Kemudahan menjalankan animasi & 4 & 5 & 9 & 4,5 & Sangat Baik \\
\hline 9 & Modifikasi yang mudah & 5 & 5 & 10 & 5 & Sangat Baik \\
\hline 10 & Pengelolaan data disc & 5 & 5 & 10 & 5 & Sangat Baik \\
\hline 11 & $\begin{array}{l}\text { Proporsional Layout (tata letak teks dan } \\
\text { gambar) }\end{array}$ & 5 & 4 & 9 & 4,5 & Sangat Baik \\
\hline 12 & Kesesuaian proporsi warna & 5 & 5 & 10 & 5 & Sangat Baik \\
\hline 13 & Kesesuaian pemilihan jenis huruf & 5 & 5 & 10 & 5 & Sangat Baik \\
\hline 14 & Kesesuaian pemilihan ukuran huruf & 5 & 5 & 10 & 5 & Sangat Baik \\
\hline 15 & Kesesuaian pemilihan musik backsong & 5 & 5 & 10 & 5 & Sangat Baik \\
\hline 16 & Kualitas tampilan animasi & 5 & 4 & 9 & 4,5 & Sangat Baik \\
\hline 17 & Kemenarikan button/navigator & 4 & 4 & 8 & 4 & baik \\
\hline 18 & Konsistensi tampilan button & 5 & 5 & 10 & 5 & Sangat Baik \\
\hline 19 & Kemenarikan desain cover & 4 & 5 & 9 & 4,5 & Sangat Baik \\
\hline
\end{tabular}




\begin{tabular}{|c|c|c|c|c|c|c|}
\hline \multirow{2}{*}{ No } & \multirow{2}{*}{ Indikator } & \multicolumn{2}{|c|}{ Responden } & \multirow{2}{*}{$\begin{array}{l}\text { Jumlah } \\
\text { Skor }\end{array}$} & \multirow{2}{*}{$\begin{array}{l}\text { Rata } \\
\text { rata }\end{array}$} & \multirow{2}{*}{ Kriteria } \\
\hline & & 1 & 2 & & & \\
\hline 20 & Kemenarikan tampilan kemasan luar & 5 & 5 & 10 & 5 & Sangat Baik \\
\hline \multicolumn{5}{|c|}{ PERSENTASE } & $95 \%$ & Sangat baik \\
\hline
\end{tabular}

Kesimpulan hasil penilaian ahli media pembelajaran secara keseluruhan maka disimpulkan bahwa jumlah nilai rata-rata dari indikator tersebut adalah 95\%. Dimana jika rentang berada pada skor $81 \leq \mathrm{X} \leq 100$ maka kecenderungan penilaian ahli media pembelajaran dinyatakan kategori "sangat layak".

Uji Coba Lebih Luas untuk menjaring informasi dalam cakupan lebih luas berkaitan dengan kualitas multimedia interaktif, subjek penelitian dalam tahap ini adalah siswa kelas 2 MTs sebanyak 40 orang yang dipilih secara random. Adapun data hasil uji coba lebih luas oleh siswa pada setiap aspeknya dapat dilihat pada Tabel 5 berikut:

Tabel 5. Data Hasil Uji Coba Kelayakan Multimedia Skala Lebih Luas oleh Siswa

\begin{tabular}{|l|c|c|}
\hline \multicolumn{1}{|c|}{ Aspek Penilaian } & $\begin{array}{c}\text { Persentasi Rata-Rata } \\
\text { Skor Responden }\end{array}$ & Kriteria \\
\hline Aspek Pembelajaran & $91,65 \%$ & Sangat baik \\
\hline Aspek Materi & $90,05 \%$ & Sangat baik \\
\hline Aspek Pemrograman & $92,05 \%$ & Sangat baik \\
\hline Aspek Tampilan Multimedia & $89,8 \%$ & Sangat baik \\
\hline Rata-rata & $90,89 \%$ & Sangat baik \\
\hline
\end{tabular}

Kesimpulan hasil penilaian dan tanggapan uji coba skala lebih luas dari 40 orang siswa keseluruhan maka disimpulkan bahwa persentase nilai rata-rata dari setiap aspek penilaiannya adalah $90,89 \%$. Dimana jika rentang berada pada skor $81 \% \leq X \leq 100 \%$ maka kecenderungan hasil uji coba terbatas dinyatakan kategori "sangat layak". Adapun persentase rata-rata dari hasil penilaian para ahli yaitu ahli materi, ahli desain dan ahli media pembelajaran dapat dilihat pada Tabel 6 berikut:

Tabel 6. Persentase Rata-rata Hasil Penilaian Kelayakan Multimedia Interaktif Pembelajaran Membaca Alquran Oleh Para Ahli

\begin{tabular}{|c|l|c|l|}
\hline No & \multicolumn{1}{|c|}{ Para Ahli } & Persentase & \multicolumn{1}{c|}{ Kriteria } \\
\hline 1 & Materi Pembelajaran & $95 \%$ & Sangat baik \\
\hline 2 & Desain Pembelajaran & $89 \%$ & Sangat baik \\
\hline 3 & Media Pembelajaran & $95 \%$ & Sangat baik \\
\hline \multicolumn{2}{|c|}{ Rata-rata } & $\mathbf{9 3 \%}$ & Sangat baik \\
\hline
\end{tabular}

Adapun persentase skor rata-rata dari hasil penilaian pada saat uji coba terbatas ditinjau dari setiap aspeknya adalah (1) aspek pembelajaran dengan persentase rata-rata 96,80\% (2) aspek materi dengan persentase rata-rata $96,80 \%$ (3) aspek pemrograman dengan persentase rata-rata $98,80 \%$, dan (4) aspek tambilan multimedia dengan persentase rata-rata 97,47\%.

Tabel 7. Hasil Pengujian Hipotesis Kelayakan Produk

\begin{tabular}{|c|c|c|c|c|}
\hline No & Tahap Pengujian & $\begin{array}{c}\text { Hasil } \\
\text { Pengujian }\end{array}$ & Kriteria Kelayakan & Kesimpulan \\
\hline 1 & Uji Ahli & $93 \%$ & sangat layak & \multirow{4}{*}{$\begin{array}{l}\text { multimedia interaktif } \\
\text { sangat layak digunakan } \\
\text { sebagai media } \\
\text { pembelajaran membaca } \\
\text { Alquran di pesantren }\end{array}$} \\
\hline 2 & Uji Coba Terbatas & $97,47 \%$ & sangat layak & \\
\hline 3 & Uji Coba Lebih Luas & $90,89 \%$ & sangat layak & \\
\hline & Rata-rata & $93,79 \%$ & sangat layak & \\
\hline
\end{tabular}


Berdasarkan hasil uji normalitas data tes awal (pretes) ternyata kedua sampel berdistribusi normal dan mempunyai varians yang homogen, maka untuk menguji hipotesis dilakukan uji $\mathrm{t}$ satu pihak, yaitu untuk mengetahui hasil belajar kelompok yang diajarkan menggunakan multimedia interaktif lebih tinggi daripada kelompok yang diajarkan menggunakan media grafis sketsa, secara statistik hipotesisnya adalah:

$\mathrm{H}_{\mathrm{o}}: \mu \mathrm{Mi} \leq \mu \mathrm{Gs}$

$\mathrm{H}_{\mathrm{a}}: \mu \mathrm{Mi}>\mu \mathrm{Gs}$

Hasil pengujian hipotesis keefektifan produk adalah sebagai berikut: nilai rata-rata postes kelas eksperimen 72,9 dan ketuntasan kelas mencapai $87,5 \%$ dari 40 siswa. Sedangkan nilai rata-rata postes untuk kelas kontrol 66,1 dan ketuntasan kelas mencapai 67,5\% dari 40 siswa. Data postes berdistribusi normal dan homogen, dengan uji t satu pihak dengan taraf nyata $\alpha=0,0,5$ dapat dilihat dari hasil belajar kelas eksperimen dengan nilai ratarata yang lebih tinggi dibanding kelas kontrol, dan hasil ketuntasan kelas eksperimen yang lebih tinggi daripada ketuntasan kelas kontrol. Kelas eksperimen telah mencapai standar ketuntasan kelas sebesar $85 \%$, sedangkan kelas kontrol belum tercapai yaitu sebesar 67,5\% .

Tabel 8. Hasil Pengujian Hipotesis Keefektifan Produk

\begin{tabular}{|l|c|c|c|l|}
\hline \multicolumn{1}{|c|}{ Data } & $\begin{array}{c}\text { Nilai } \\
\text { rata-rata }\end{array}$ & $\mathbf{t}_{\text {hitung }}$ & $\mathbf{t}_{\text {tabel }}$ & \multicolumn{1}{c|}{ Kesimpulan } \\
\hline $\begin{array}{l}\text { Postes } \\
\text { Eksperimen }\end{array}$ & 72,9 & 2,988 & 1,994 & $\begin{array}{l}\text { hasil belajar membaca Alquran siswa yang } \\
\text { diajarkan dengan multimedia interaktif } \\
\text { lebih tinggi daripada siswa yang diajarkan } \\
\text { dengan media grafis sketsa }\end{array}$ \\
\cline { 1 - 5 } Postes Kontrol & 66.125 & & \\
\hline
\end{tabular}

Harga ini diasumsikan dengan tabel nilai persentil untuk distribusi t dengan $\alpha=0,05$ dan diperoleh $t_{\text {tabel }}=1,994$ dan $t_{\text {hitung }}=2,988$ maka $\mathrm{t}_{\text {hitung }}>\mathrm{t}_{\text {tabel }}$ sehingga $\mathrm{H}_{\mathrm{o}}$ ditolak dan $\mathrm{H}_{\mathrm{a}}$ diterima itu artinya hipotesis keefektifan produk diterima yaitu hasil belajar siswa yang diajarkan dengan menggunakan multimedia interaktif lebih tinggi daripada yang menggunakan media grafis sketsa.

\section{Pembahasan}

Pengujian kelayakan multimedia pembelajaran interaktif ini untuk mengetahui tingkat kelayakan suatu produk yang telah dibuat atau yang sedang dikembangkan. Pada pengujian kelayakan multimedia interaktif ini melalui tiga tahap, dengan hasilnya masingmasing sebagai berikut:

a. Hasil penilaian kelayakan media pembelajaran interaktif oleh validator ahli dari segi aspek : (1) materi pembelajaran 95 $\%$; (2) desain pembelajaran $89 \%$ dan (3) media pembelajaran $95 \%$. Secara keseluruhan rata-rata penilaian oleh validator ahli terhadap multimedia interaktif untuk pembelajaran membaca Alquran adalah sebesar $93 \%$. Sehingga, berdasarkan uji kelayakan oleh para ahli maka multimedia interaktif untuk pembelajaran membaca Alquran sangat layak digunakan. b. Hasil penilaian kelayakan multimedia pembelajaran interaktif pada uji coba terbatas dari aspek : (1) pembelajaran $96,80 \%$; (2) materi $96,80 \%$; (3) pemrograman $98,80 \%$ dan (4) tampilan multimedia 97,47\%. Secara keseluruhan, penilaian pada tahap uji coba terbatas terhadap multimedia interaktif untuk pembelajaran membaca Alquran sebesar $97,47 \%$. Sehingga, berdasarkan uji coba kelayakan skala terbatas maka multimedia interaktif untuk pembelajaran membaca Alquran sangat layak digunakan.

c. Hasil penilaian kelayakan multimedia pembelajaran interaktif pada uji coba lebih luas dari aspek : (1) pembelajaran 91,65\% ; (2) materi $90,05 \%$; (3) pemrograman $92,05 \%$ dan (4) tampilan multimedia $89,80 \%$. Secara keseluruhan, penilaian pada tahap uji coba lebih luas terhadap multimedia interaktif untuk pembelajaran membaca Alquran sebesar 90,89\%.. Sehingga, berdasarkan uji coba kelayakan skala lebih luas maka multimedia interaktif untuk pembelajaran membaca Alquran sangat layak digunakan.

Terlihat bahwa dari keseluruhan hasil penilaian kelayakan tersebut didapat hasil bahwa media tersebut sangat layak digunakan sebagai media pembelajaran karena rata-rata hasil dari uji kelayakan media pembelajaran 
tersebut adalah sangat layak. Walaupun hasil uji telah menunjukkan kelayakan, namun peneliti tetap melakukan revisi berdasarkan hasil dan saran dari ketiga validator, pada uji coba kelayakan skala terbatas begitu juga pada uji coba kelayakan skala lebih luas.

Setelah selesai melaksanakan uji kelayakan yang hasilnya menunjukkan bahwa multimedia pembelajaran interaktif telah sangat layak untuk digunakan, maka langkah selanjutnya adalah melakukan uji keefektifan tentang penggunaan multimedia interaktif untuk pembelajaran membaca Alquran di pesantren. Pada uji keefektifan multimedia interaktif ini, kelas eksperimen diberi perlakuan dengan menggunakan multimedia interaktif dan kelas kontrol diberi perlakuan dengan menggunakan media grafis sketsa selama empat kali pertemuan, kedua kelas diberikan postes untuk mengetahui pemahaman siswa pada materi pelajaran yang telah diberikan. Maka didapatlah nilai rata-rata postes kelas eksperimen 72,9 dan ketuntasan kelas mencapai 87,5\% dari 40 siswa. Sedangkan nilai rata-rata postes untuk kelas kontrol 66,1 dan ketuntasan kelas mencapai 67,5\% dari 40 siswa. Data postes berdistribusi normal dan homogen, dengan uji t satu pihak dengan taraf nyata $\alpha=0,0,5$ didapat bahwa keefektifan multimedia interaktif dalam pembelajaran membaca Alquran lebih tinggi dibandingkan dengan media grafis sketsa, dapat dilihat dari hasil belajar kelas eksperimen dengan nilai rata-rata yang lebih tinggi dibanding kelas kontrol, dan hasil ketuntasan kelas eksperimen yang lebih tinggi daripada ketuntasan kelas kontrol. Kelas eksperimen telah mencapai standar ketuntasan kelas sebesar $85 \%$, sedangkan kelas kontrol belum tercapai yaitu sebesar $67,5 \%$. Hasil pengujian ini menunjukkan bahwa hasil belajar siswa yang diajarkan dengan menggunakan multimedia interaktif lebih tinggi daripada yang menggunakan media grafis sketsa.

Hasil penelitian ini sejalan dengan dua peneliti sebelumnya yang juga menggunakan multimedia interaktif yaitu: (1) Hasil penelitian tentang Pengaruh Penggunaan Multimedia Pembelajaran Dan Kecerdasan Emosional Santri Terhadap Hasil Belajar TIK yang dilakukan oleh Sony (2011), menemukan bahwa penggunaan multimedia $\mathrm{CD}$ interaktif lebih baik secara signifikan dibandingkan dengan Penggunaan multimedia VCD terhadap hasil belajar TIK. (2) Hasil penelitian tentang penggunaan media pembelajaran interaktif berbasis komputer dan sikap inovatif terhadap hasil belajar TIK yang dilakukan oleh Resien (2010), menemukan bahwa siswa yang diajar dengan menggunakan media pembelajaran interaktif berbasis komputer memperoleh hasil belajar yang lebih baik khususnya pada mata pelajaran TIK.

\section{PENUTUP}

Dihasilkan produk pengembangan berupa Multimedia Interaktif Pembelajaran Membaca Alquran dengan materi pokok Makharij Al-Huruf untuk siswa kelas II Pesantren Ar-Raudhatul Hasanah Medan dalam bentuk kepingan compact disc (CD) beserta manual book, yang dapat digunakan untuk pembelajaran individual, klasikal/kelompok dengan menggunakan perangkat komputer dengan CD-ROM (Compact Disc-Read Only Memory) dan atau dengan media bantuan LCD (Liquid Crystal Display). Produk multimedia pembelajaran ini terdiri atas beberapa komponen isi diantaranya; a) halaman pembuka, b) halaman menu utama, terdiri dari beberapa bagian diantaranya: (1) halaman kompetensi, (2) halaman materi, (3) halaman Latihan, (4) halaman Tes, (5) halaman profil. Prosedur pengembangan multimedia ini melalui tiga tahapan utama yaitu (1) tahap perencanaan, (2) tahap desain, (3) tahap pengembangan. Pada tahap pengembangan meliputi beberapa tahap yang terdiri dari validasi ahli, uji coba terbatas dan uji coba lebih luas kemudian dilanjutkan uji efektifitas produk. Multimedia interaktif ini tergolong layak digunakan sebagai sumber belajar sesuai dengan hasil validasi ahli yang menunjukkan kelayakan produk memperoleh persentase rata-rata skor 93\% (kategori sangat layak), uji coba terbatas menunjukkan kelayakan produk memperoleh persentase ratarata skor $97,47 \%$ (kategori sangat layak), dan uji coba terbatas menunjukkan kelayakan produk memperoleh persentase rata-rata skor 90,89\% (kategori sangat layak).

Produk multimedia interaktif dapat meningkatkan penguasaan kompetensi pembelajaran membaca Alquran pada materi pokok makharij al-huruf yang diwujudkan dalam skor tes hasil belajar pada evaluasi sumatif yang merupakan uji efektivitas produk. Hal ini terlihat dari nilai rata-rata postes kelas yang menggunakan multimedia interaktif mencapai 72,9 dan ketuntasan kelas mencapai $87,5 \%$ dari 40 siswa. Sedangkan nilai rata-rata postes untuk kelas yang menggunakan media 
grafis sketsa mencapai 66,1 dan ketuntasan kelas mencapai 67,5\% dari 40 siswa. Data postes berdistribusi normal dan homogen, dengan uji t satu pihak dengan taraf nyata $\alpha=$ 0,0,5 didapat bahwa hasil belajar membaca Alquran siswa yang diajarkan dengan multimedia interaktif lebih tinggi daripada hasil belajar membaca Alquran yang siswa diajarkan dengan media grafis sketsa.

\section{DAFTAR PUSTAKA}

A'zami, Muhammad. 2005. The History of The Qur'anic Text From Revelation to Compilation: Sejarah Teks Al-Qur'an dari Wahyu Sampai Kompilasinya. Penerjemah: Anis Malik Thaha, Jakarta: Gema Insani Press.

Al-Mujahid, A. Toha Husein. 2011. Ilmu Tajwid Pegangan Para Pengajar AlQur'an dan Aktivitas Dakwah, Jakarta: Darus Sunnah.

Al-Qaradhawi, Yusuf. 2007. Menumbuhkan Cinta kepada Al-Qur'an, Penerjemah: Ali Imron. Yogyakarta: Mardhiyah Press.

Annuri, Ahmad. 2010. Panduan Tahsin Tilawah Al-Qur'an \& Ilmu Tajwid, Jakarta: Pustaka Al-Kautsar.

Arsyad, Azhar. 2006. Media Pembelajaran. Jakarta: PT. Raja Grafindo Persada.

As-Sa'di, Abdurrahman. 2008. Bacalah AlQur'an Seolah-olah Ia Diturunkan Kepadamu, Penerjemah: Abdurrahim, Jakarta: Hikmah.

As-Shalih, Subhi. 2000. Membahas Ilmu-Ilmu Al-Qur'an, Jakarta: Pustaka Firdaus.

Australian Council for Educational Research, The potential impact of competency based approaches on literacy education. p.3. 8 Desember 2011 (http:/www.gu.edu.au/school/cls//clearin ghouse/1995-com/content12.html.).

Borg, W. Gall, Joyce P. \& Gall, Meredith D. 2002. Educational research. An introduction $\left(7^{\text {nd }}\right.$ ed). New York \& London: Longman.

Budiman, R. 2006. Media Pembelajaran. Bandung: PPPG Tertulis.

Chapman, N. \& Chapman, J. 2004. Digital multimedia (2nd ed). London: John Wiley \& Sons, Ltd.

Clarebout, G., Elen, J. 2008. Advice on Tool Use in Open Learning environments. Journal of Educational Multimedia and Hypermedia. 17(1). 81-97.
Collins J, Hammond M. and Wellington J. 2002. Teaching and Learning with Multimedia, London: Routledge.

Constantinescu, A. I. 2007. Using technology to assist in vocabulary acquisition and reading comprehension. The Internet TESL Journal, Vol. XIII, No. 2, February 2007. Diunduh tanggal 7 Desember 2011, dari

http://iteslj.org/Articles/ConstantinescuVocabulary.html.

Deimann, M., \& Keller, J. M. 2006. Volitional Aspects of Multimedia Learning. Journal of Educational Multimedia and Hypermedia. 15(2). 137-158.

Dhofier, Zamakhsyari. 1996. Tradisi Pesantren, Jakarta; LP3ES.

Dick, W. Carey dan Carey, L. 2005. The systematic design of instruction. United States

of America: Scott Foresman and Company.

Ena, Ouda Teda. (2001). Membuat Media Pembelajaran Interaktif dengan Piranti Lunak Presentasi. Yogyakarta: Indonesian Language and Culture Intensive Course Universitas Sanata Dharma.

www.ialf.edu/kipbipa/papers/oudatedaen a.doc.

Federspiel, Howard M. 1996. Kajian Al-Qur'an di Indonesia. terj. Drs. Tajul Arifin, M.A. Bandung, Mizan.

Gusmian, Islah. 2003. Khazanah Tafsir Indonesia, dari Hermeneutika hingga Ideologi, Jakarta: Teraju.

Hakim, Lukmanul. 2004. Cara Ampuh Menguasai Macromedia Flash Professional 8.0. Jakarta: PT Elex Media Komputindo.

Hannafin, M. J. \& Peck, K. L. 1988. The design, development, and evaluation of instructional software. New York: Macmillan Publishing Company.

Harp, S.F, \& Mayer, R.E. 1997. The role of ilnterest in learning from scientific text and illustrations: On the distinction between emotional interest and cognitive interest. Journal of Educational Psychology. 89(1). 92-102.

Heinich, R., Molenda, M., Russel, J. D. \& Smalindo, S. E. 2002. Instructional Media and Technologies for Learning. New Jersey: Courier Kendallville. 
Huk, T., Steinke, M., \& Floto, C. 2003. Computer Animations as Learning Objects : What is an Efficient Instructional Design, and For Whom?. Proceedings of IADIS International Conference.

Khalid, Amru. 2005. Ibadah Sepenuh Hati, Penerjemah: Saiful Haq, Solo: Aqwam.

Kinshuk, \& Patel, A. 2003. Optimising Domain Knowledge Representation with Multimedia Objects. In S. Naidu (Ed.) Learning \& Teaching with Technology Principles and Practices. London: Kogan (55-68).

Leacock, T. L., \& Nesbit, J. C. 2007. A Framework for Evaluating the Quality of Multimedia Learning Resources. Educational Technology \& Society, 10 (2). 44-59.

Lee, W. W. \& Owens, D. L. 2004. Multimediabased instructional design: Computerbased training, web-based training, distance broadcast training, performance based solution $\left(2^{\text {nd }}\right.$ ed). San Francisco: Pfeiffer A Wiley Imprint.

Mayer, Richard E. (2001). Multimedia Learning. terj: Teguh W. Utomo. Yogyakarta: Pustaka Pelajar.

Miarso, Yusufhadi. 2009. Menyemai Benih Teknologi Pendidikan. Jakarta: Prenada Media.

Muller, D. A., Lee, K. J., \& Sharma, S. D. 2008. Coherence or Interest : Which is most Important in On Line Multimedia Learning?. Australian Journal of Educational Technology. 24(2), 211-221.

Park, S., \& Lim. J. 2007. Promoting Positive Emotion in Multimedia Learning Using Visual illustrations. Journal of Educational Multimedia and Hypermedia. 16(2). 141-163.

Phillips, Rob. (1997). The developer's handbook to interactive multimedia: a practical guide for educational applications. London: Kogan Page Ltd.

Qaraati, Mohsen. 2005. Tafsir Untuk Anak Muda Surah Luqman, Penerjemah: M. Ilyas, Jakarta: Al-Huda.

Quthb, Sayyid. 2004. Indahnya Al-Qur'an Berkisah, Gema Insani Press, Jakarta.

Reigeluth, C. M, 1983. Instructional Design Theories and Models An Overview of their Current Status. London: Lawrence Erlbaum Associates.
Sadiman, A.S., Rahardjo, R., Haryono, A. \& Rahardjito. 2002. Media Pendidikan; Pengertian, Pengembangan dan Pemanfaatannya. Jakarta: Rajawali.

Salim, Shafwat Mahmud. 2009. Fathu Rabbi al-Bariyyah Syarah al-Muqaddimah alJazariyah fi ilmi at-Tajwid wa Ma'ahu Manzhumah al-Jazariyah. Jeddah: Maktabah Rawai'u al-Mamlakah.

Sanaky, Hujair AH. 2011. Media Pembelajaran, Buku Pegangan Wajib Guru dan Dosen. Yogyakarta: Penerbit Kaukaba.

Sanjaya, Wina. 2007. Strategi Pembelajaran, Berorientasi Standar Proses Pendidikan, Jakarta: Kencana Prenada Media.

Shihab, M. Quraish. 2000. Wawasan AlQur'an, Tafsir Maudhu'i atas Pelbagai Persoalan Umat, Bandung: Mizan. 2002. Tafsir Al-Mishbah, Pesan, Kesan dan Keserasian Al-Qur'an, Volume 7. Jakarta: Lentera Hati.

2007. Membumikan Al-Qur'an, Fungsi dan Peran Wahyu dalam Kehidupan Masyarakat, editor Ihsan Ali Fauzi, Bandung: Mizan.

2007. Mu'jizat Al-Qur'an, Ditinjau dari Aspek Kebahasaan, Isyarat Ilmiah, dan Pemberitaan Gaib, Bandung: Mizan.

Smaldino, Sharon E., Lowther, Deborah L., dan Russell, James D. 2011. Instructional Technology \& Media for Learning Teknologi Pembelajaran dan Media untuk Belajar. terj: Arif Rahman. Jakarta: Kencana.

Sudatha dan Tegeh. 2009. Desain Multimedia Pembelajaran. Buku Ajar Jurusan Teknologi Pendidikan, Universitas Ganesha, Singaraja.

Sukardi. 2011. Metodologi Penelitian Pendidikan Kompetensi dan Praktiknya. Jakarta Bumi Aksara.

Suparman, M. Atwi. 2001. Desain Instruksional, Pekerti Mengajar di Perguruan Tinggi. Jakarta: Universitas Terbuka.

Sutopo A. H. 2003. Multimedia Interaktif dengan Flash. Yogyakarta: Graha Ilmu.

Sweller, J. 1994. "Cognitive Load Theory, learning difficulty, and instructional design". Learning and Instruction. 4. 295-312

Sya'rawi, Syekh Mutawalli. 2004. Tafsir Sya'rawi, Jilid I, Jakarta: Duta Azhar. 
Thabathaba'i, Sayyid Muhammad Husain. 2000. Memahami Esensi Al-Qur'an, Penerjemah: Idrus Alkaf, Jakarta: Lentera.

Waldopo. 2002. Penelitian dan pengembangan, pendekatan dalam mengembangkan produk-produk di bidang pendidikan pembelajaran. Jurnal Teknodik. Desember 2002. Jakarta: Pustekkom
Widoyoko, Eko Putro. 2009. Evaluasi Program Pembelajaran, Panduan Praktis Bagi Pendidik dan Calon Pendidik. Yogyakarta: Pustaka Pelajar.

Yunus, Mahmud. 2001. Sejarah Pendidikan Islam di Indonesia. Jakarta: Hidakarya Agung.

Yusuf, Pawit M. 2010. Komunikasi Instruksional Teori dan Praktik, Jakarta: Bumi Aksara. 